\title{
Early induction of orthotropic shoots in Coffea canephora
}

\author{
Marcelo Curitiba Espindula ${ }^{1}$ (D) , Larissa Fatarelli Bento de Araújo ${ }^{2}$, Raquel Schmidt ${ }^{3}$, \\ Jairo Rafael Machado Dias ${ }^{4}$, Rodrigo Barros Rocha ${ }^{1}$
}

10.1590/0034-737X202067040005

\begin{abstract}
In Coffea canephora, the number of orthotropic shoots is directly related to plant yield. The objective of this study was to evaluate the vegetative and yield performance of Coffea canephora, from the botanical variety Conilon, under different management systems for early emission of orthotropic shoots. The experiment was carried out in Ouro Preto do Oeste, Rondônia, between November 2011 and May 2014. Three types of management techniques were tested for early induction of orthotropic shoots in coffee trees $(\mathrm{T} 1=$ bending of the orthotropic shoot; $\mathrm{T} 2=$ apical pruning of the orthotropic shoot, $\mathrm{T} 3=$ free growing). The experiment was conducted in a randomized block design with 20 replicates. Each block consisted of a clonal genotype (clone) from the Embrapa Coffee Breeding Program. The techniques pruning and apical pruning were efficient to induce early growth of orthotropic shoots in Coffea canephora, resulting in higher yield in the first commercial bean production.
\end{abstract}

Keywords: Conilon; apical dominance; bending; apical pruning.

\section{INTRODUCTION}

In Coffea canephora, the number of orthotropic shoots is directly related to plant yield (Verdin Filho et al., 2014). Therefore, the training in the multiple stem system is recommended for $C$. canephora trees, unlike $C$. arabica, which is trained in the single stem system. However, although C. canephora plants are able to produce sprouts with potential to become supporting stems for production shoots, environmental factors such as temperature and water availability (Silva et al., 2010; Partelli et al., 2013) in association with time of crop establishment (Espindula $e t$ al., 2015) and genetic variations (Rodrigues et al., 2017) influence the expression of this trait, especially in the initial growth phase.

To reduce these potential losses, techniques of induction of early sprouting can help in the formation of clonal crops. Advantages of using these techniques are the standardization of the crop and the possibility of determining the number of orthotropic shoots per cultivated area in the first months after the implantation of the crop, which contributes directly to increase yield as early as in the first harvest (Espindula et al., 2016). In addition, it allows the adjustment of the crop to the system of programmed pruning cycle (Morais et al., 2012; Partelli et al., 2013).

In general, the induction of adventitious shoots in agricultural crops has been associated with factors such as response to hormonal changes caused by environmental stresses (Taiz et al., 2017), use of growth regulators (Ono et al., 2004), management techniques (Araujo \& Siqueira, 2008; Marques et al., 2012, Silva et al., 2012), or even genetic variation between plants. For coffee plants, the induction of sprouting has been carried out mainly by management techniques, especially plant bending (Schmidt et al., 2015; Rodrigues et al., 2017) and apical pruning (Rezende et al., 2017). These techniques

\footnotetext{
Submitted on February 04th, 2020 and accepted on May 24th, 2020.

${ }^{1}$ Embrapa, Porto Velho, Rondônia, Brazil. marcelo.espindula@embrapa.br; rodrigo.rocha@embrapa.br

${ }^{2}$ Fundação Universidade Federal de Rondônia, Programa de Pós-Graduação em Ciências Ambientais, Rolim de Moura, Rondônia, Brazil. larissafatarelli@gmail.com

${ }^{3}$ Universidade Federal do Espírito Santo, Programa de Pós-Graduação em Genética e Melhoramento, Alegre, Espírito Santo, Brazil. schmidt_raquel@hotmail.com

${ }^{4}$ Fundação Universidade Federal de Rondônia, Departamento de Agronomia, Rolim de Moura, Rondônia, Brazil. jairorafaelmdias@gmail.com

*Corresponding author: marcelo.espindula@embrapa.br
} 
promote growth of lateral shoots by breaking the apical dominance and changing the balance between auxins and cytokinins and the availability of carbohydrates mobilized for growth (Taiz et al., 2017).

Although farmers in the major producing regions of $C$. canephora in Brazil already use techniques of induction of early growth of orthotropic shoots, the contribution of these techniques to increasing yield in the first commercial harvest has not yet been quantified. Thus, the objective of this study was to evaluate the vegetative and productive performance of $C$. canephora cultivated under different managements for early sprouting of orthotropic shoots.

\section{MATERIAL AND METHODS}

The experiment was conducted at the Experimental Station of Embrapa Rondônia in the municipality of Ouro Preto do Oeste, Rondônia (1043'55' South Latitude; 62 ${ }^{\circ} 15^{\prime} 19^{\prime \prime}$ 'West Longitude, 245 meters altitude), from November 2011 to May 2014. The climate of the region is Aw - tropical savanna, according to Köppen classification, average annual temperature of $25^{\circ} \mathrm{C}$, and average annual rainfall of 2,000 $\mathrm{mm}$. The rainy season begins in OctoberNovember and ends in April-May.

The experiment was installed in a Medium-textured Red-Yellow Latosol. The land was fallowed for ten years and the soil chemical attributes were determined in the 0 $20 \mathrm{~cm}$ layer (Table 1) before the soil preparation.

Maximum, average and minimum temperature, relative air humidity, accumulated evapotranspiration from class $\mathrm{A}$ tank, and rainfall data were obtained from automatic station (Figure 1).

Three management practices were tested for early induction of orthotropic shoots in C. canephora 'Conilon' (T1 = bending of orthotropic stem; T2 = apical pruning of orthotropic stem; T3 = free growing), over 30 months. The experiment was conducted in a randomized block design with 20 replicates. Each block consisted of a clonal genotype (clone) of Conilon coffee derived from germoplasm collections of the Embrapa Coffee Breeding Program, therefore, 20 genotypes were used. The genotypes different were interpreted as the effect of blocks aiming to maximize the homogeneity within and heterogeneity between blocks, since the aim of the study was to evaluate the average behavior of Conilon botanical variety when using induction techniques.
Each experimental plot consisted of five plants in sequence within the planting row. The useful plot was formed by the three central plants of the experimental plot. Plants were spaced $3 \mathrm{~m}$ between rows and $2 \mathrm{~m}$ within the row.

The experimental area was set up with the planting of the seedlings on November 28, 2011. Field preparation consisted of one plowing and two harrowing operations. The seedlings were planted into $0.4 \times 0.4 \times 0.4 \mathrm{~m}$ square holes, adding $200 \mathrm{~g}$ of triple superphosphate, $50 \mathrm{~g}$ of potassium chloride, $50 \mathrm{~g}$ of FTE, and $100 \mathrm{~g}$ of limestone.

The cultural treatments, during the whole experimental period, were carried out following the technical recommendations for the crop in the state of Rondônia (Marcolan et al., 2009). The experiment was conducted in dried conditions, without supplementary irrigation.

Ninety days after seedling transplanting, we begin the management practices to induce lateral sprouting in the coffee trees. A bamboo stem was used to bow the main stem of the plant near the ground, in an east-west direction, to expose the stem base to the rising sun. The apex was pruned with shears, removing the shoots and leaving only one or two leaf pairs per plant. The plants in the free growing treatment did not receive any type of management.

Seventy days after the implementation of the treatments (management practices), the number of orthotropic shoots was determined by direct counting and thinning was carried out to remove excess of shoots and maintain up to five shoots per plant.

At 540 days (18 months) after the implementation of the management practices, the orthotropic shoots were recounted. The recount was done to determine the number of branches during the blossom of the first commercial harvest.

After 810 days (27 months) after the implementation of the management practices, the following vegetative characteristics were determined: number, length, and diameter of the orthotropic shoots; crown diameter; and number and length of plagiotropic shoots.

Orthotropic shoots were counted directly on the trees; shoot length was measured from the shoot insertion point to the apex; shoot diameter was measured with a digital caliper at $5 \mathrm{~cm}$ from the insertion

Table 1: Chemical attributes of the Red-Yellow Latosol

\begin{tabular}{|c|c|c|c|c|c|c|c|c|c|c|}
\hline \multirow{2}{*}{$\begin{array}{l}\text { Water } \\
\text { pH }\end{array}$} & $\mathbf{P}$ & $\mathbf{K}$ & $\mathbf{C a}$ & Mg & $\mathbf{A l}+\mathbf{H}$ & Al & SB & CTC & \multirow{2}{*}{$\begin{array}{c}\text { MO } \\
\mathrm{g} \mathrm{kg}^{-1}\end{array}$} & \multirow{2}{*}{$\frac{\mathrm{V}}{\%}$} \\
\hline & $\overline{\mathrm{mg} \mathrm{dm}^{-3}}$ & \multicolumn{7}{|c|}{$\mathrm{cmol}_{\mathrm{c}} \mathrm{dm}^{-3}$} & & \\
\hline 5.6 & 4 & 0.19 & 2.66 & 0.54 & 2.97 & 0.0 & 3.39 & 6.36 & 20.2 & 53 \\
\hline
\end{tabular}

$\mathrm{pH}\left(\mathrm{H}_{2} \mathrm{O}-1: 2.5\right) ; \mathrm{Ca}^{2+}, \mathrm{Mg}^{2+}$ and $\mathrm{Al}^{3+}$ : extractor $\mathrm{KCl} 1 \mathrm{~mol} \mathrm{dm}^{-3} ; \mathrm{P}$ and $\mathrm{K}$ : Mehlich-1 extractor; $\mathrm{H}+\mathrm{Al}$ : calcium acetate extractor $0.5 \mathrm{~mol}$ $\mathrm{dm}^{-3}$ at $\mathrm{pH} 7.0$.

Rev. Ceres, Viçosa, v. 67, n.4, p. 281-287, jul/aug, 2020 
of the shoot on the main shoot. Crown diameter in both north-south and east-west direction was measured at the medium height of the plant. Length of plagiotropic shoots was measured from insertion point to the apex of five plagiotropic shoots per plant. In the same period, grain yield (at $12 \%$ humidity) was determined based on grains harvested from the useful plot and converted into bags of $60 \mathrm{~kg}$ per ha (hectare).

Data were analyzed by ANOVA $(\mathrm{p} \leq 0.05)$ and, when significant effects were detected, the Tukey's test ( $\mathrm{p} \leq$ 0.05) was applied.

\section{RESULTS AND DISCUSSION}

Both techniques, bending and apical pruning, were efficient to induce early orthotropic shoots in Coffea canephora. As early as 70 days after induction, the plants had on average seven orthotropic shoots (Figure 2), that is, double the number of orthotropic branches compared with the plants in free growing (3.4 shoots). This number is higher than the recommended for the species to express its maximum productive potential at the first harvest in the edaphoclimatic conditions of Amazon Region (Espindula et al., 2015).
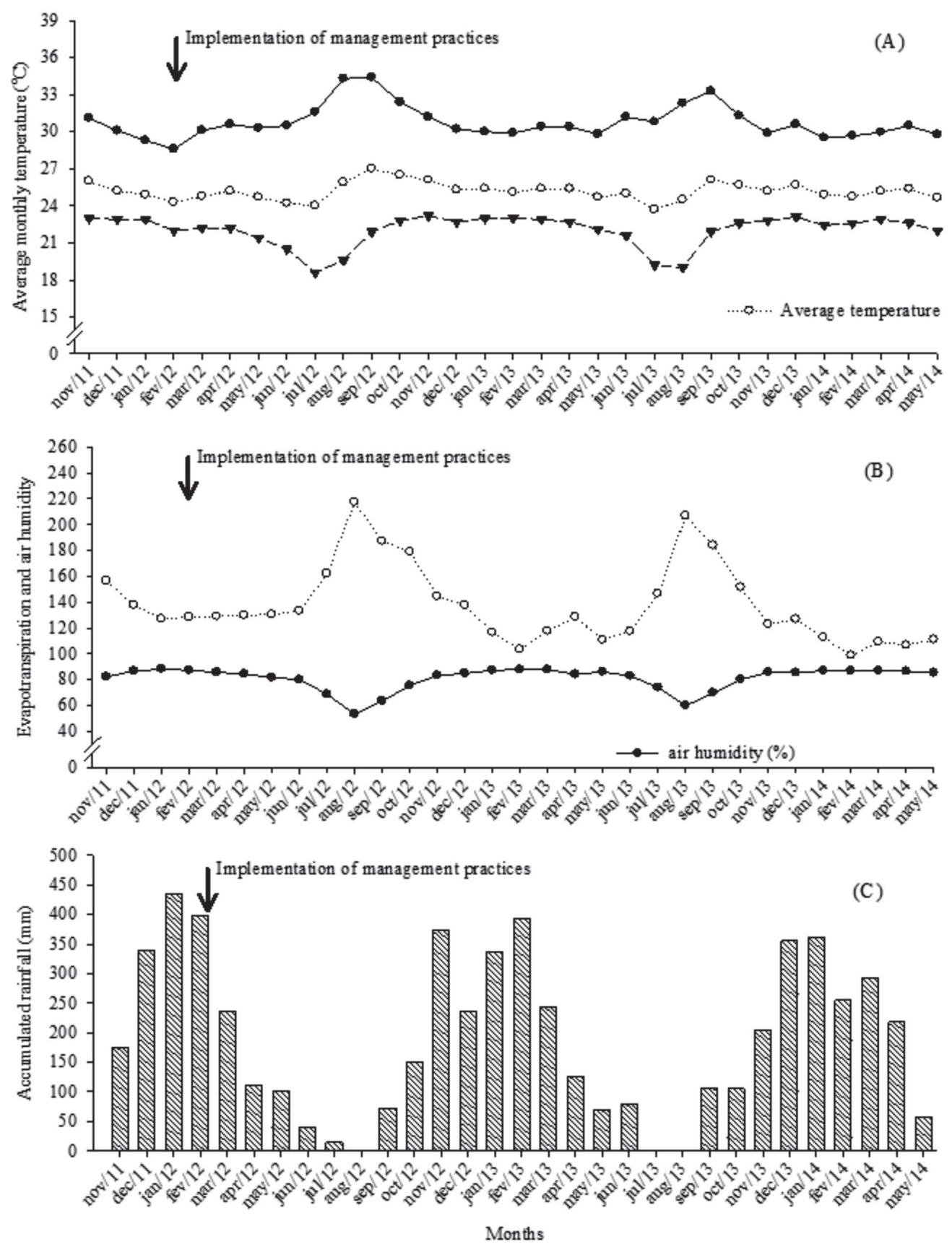

Figure 1: Maximum, average and minimum temperatures, humidity, evapotranspiration, and precipitation, from November 2011 to May 2014. 
The early growth of shoots is associated with the breakdown of the apical dominance by auxin and the availability of carbohydrates to the growing parts of the plant. By bending the plants, the auxin transport towards the root is altered and/or blocked. These modifications change the concentration of this hormone near the axillary buds and interrupt the synthesis of estrigolactone, which is the hormone responsible for activating the gene branched 1 that suppresses the growth of axillary buds (Taiz et al., 2017) and inhibits local biosynthesis of cytokinin (El-Show et al., 2013). The lack of regulation by strigolactone and increased levels of cytokinins close to axillary buds induce cells to resume cell division and, thus, the growth of branches.

Removal of the shoot apex by pruning also reduces the apical supply of auxin to the stem and interferes with its sugar sink activity. As a result, sugars, which normally flow towards the end of the stem via phloem, are transported to the region of the axillary buds, which stimulates shoot growth (Mason et al., 2014).

In addition, the early growth of orthotropic shoots allows the standardization of branch age by reducing etiolation of late shoots growing in the shade within the tree crown (Schmidt et al., 2015), as well as the renewal of branches by applying the programmed pruning cycle (Morais et al., 2012), which rejuvenates and maintains plant productivity (Partelli et al., 2013).

At 540 days after the implantation of the practices, when the plants entered the productive phase forming inflorescences, and at 810 days, at the first harvest, the number of supporting stems induced by bending and apical pruning were similar (Figure 2). However, the number of shoots of both periods and managements was greater than that produced by plants in free growing.

At 540 days after the implantation of the management practices, there was high similarity between the number of stems of bending and apical pruning due to the removal of excess stems, sprout thinning, at 70 days after induction to ensure the number of stems per plant recommended for the crop (Espindula et al., 2015). However, even after removing the excess shoots, the treatments using the induction techniques had more stems than those conducted in free growing.

Despite the lower number of orthotropic shoots, the treatment without induction provided a number of branches considered satisfactory for denser plantations in which fewer branches are used per plant, two or three (Verdin Filho et al., 2014). This result suggests that, for these cases, there is no need to use induction techniques. However, we must consider that genotypes of $C$. canephora have considerable genetic variability for the vegetative components (Ferrão et al., 2008; Rocha et al., 2013) and that the populations that gave origin to the coffee varieties grown in the main producing regions in the world are genetically different (Montagnon et al., 2012). In Brazil, this difference exists both among 'Conilon' populations cultivated in the states of Espírito Santo and Rondônia and between 'Conilon' and 'Robusta' populations cultivated only in Rondônia (Souza et al., 2013).

Regarding the vegetative variables, we found differences between the systems of conduction only for diameter of orthotropic shoots and number of plagiotropic branches. The free-growing plants had shoot diameter $12 \%$ and $18 \%$ higher than the plants conducted with apical

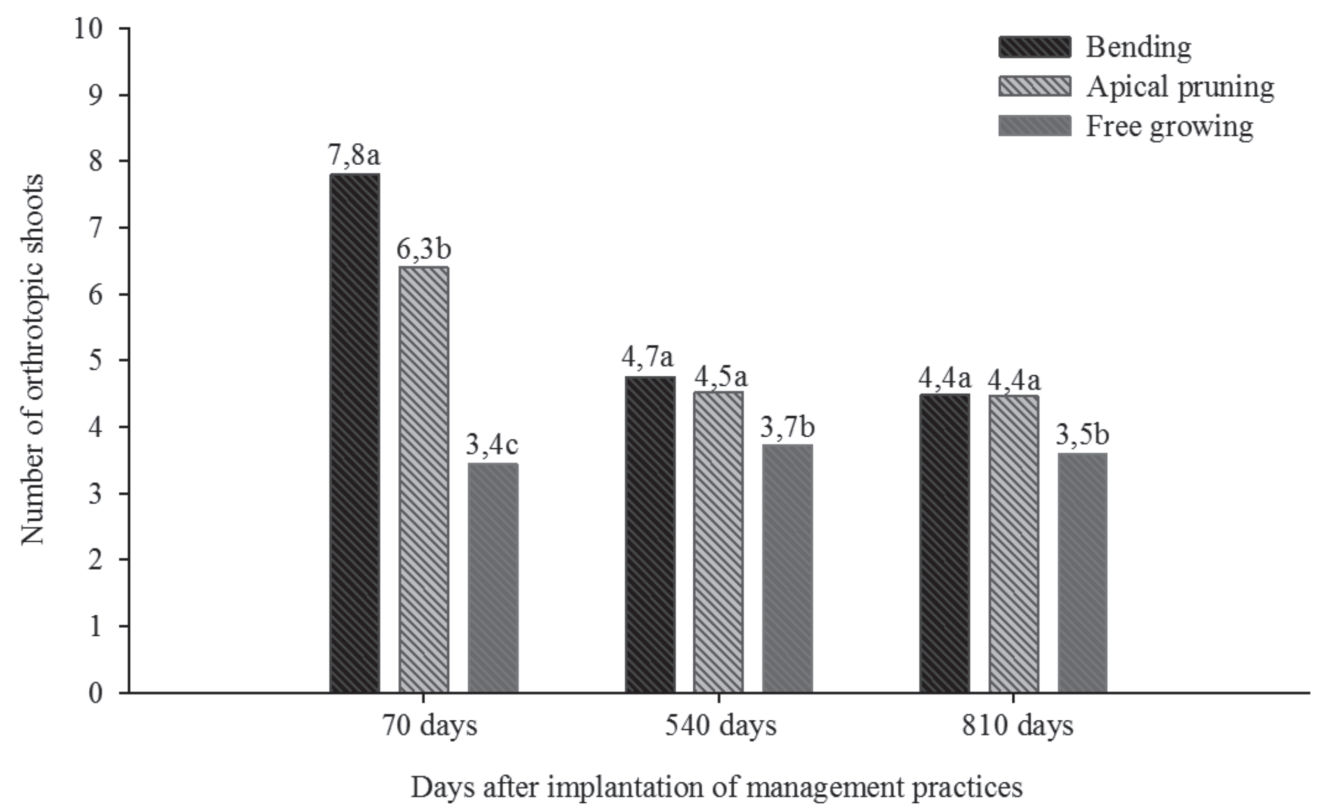

Figure 2: Number of orthotropic shoots of $C$. canephora in crop formation under different managements. 
pruning and bending, respectively. On the other hand, the free-growing plants had fewer plagiotropic branches than the pruned plants and had number of plagiotropic branches similar to the bent plants (Figure 3B). Bean production of plants induced by bending and apical pruning was similar (Figure 3F). However, the production obtained in these treatments was approximately $30 \%$ higher than that of free growing plants.

The smaller diameter of orthotropic shoots in induced plants (Figure 3B) suggest competition can exist between shoots. However, although the lower number of shoots in non-induced plants results in loss of yield potential, the greater diameter of these stems, resulting from the less competition between them, may be a positive characteristic. This is because from the second production onward the weight of the fruits can bend the support stems, hindering cultural treatments. This bending is also related to the genetic characteristics of the clonal materials used (Dalcomo et al., 2015).

The higher yield of bent or pruned plants compared with free-growing plants is related to the higher number of orthotropic shoots (Figure 2) and plagiotropic branches (Figure 3D) and indicate the efficiency of the methods to increase coffee productivity. However, the study was conducted under rainfed conditions and the plants underwent two periods of drought, from May to September

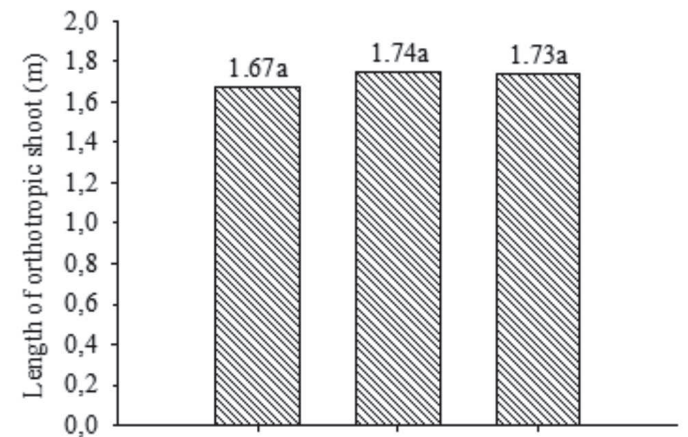

(A)

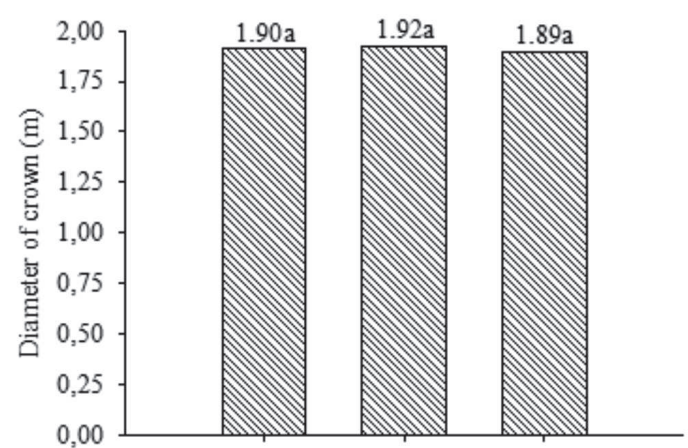

(C)

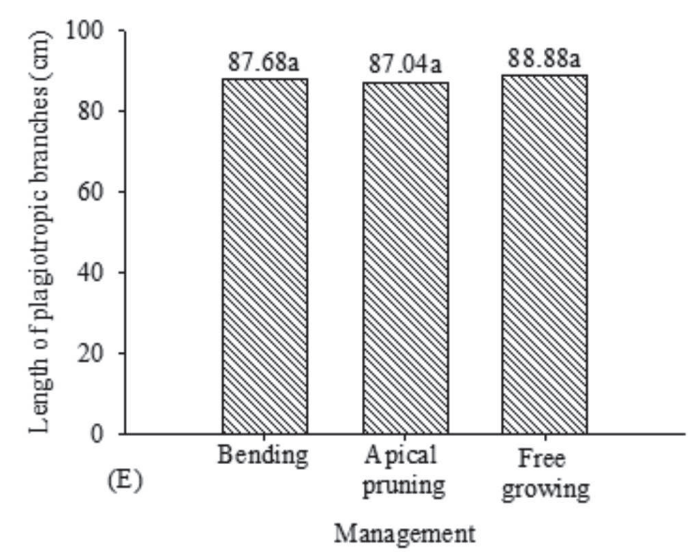

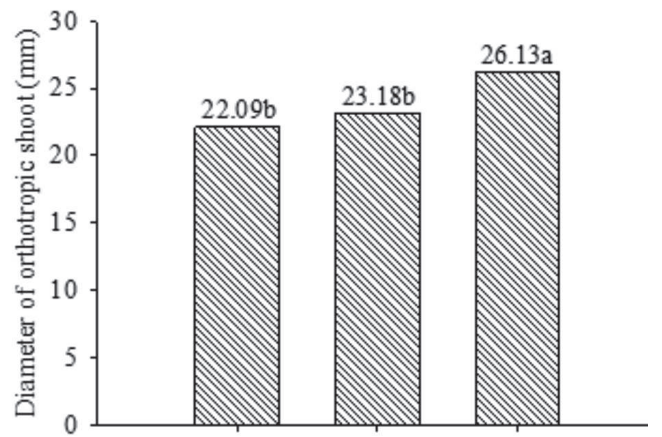

(B)

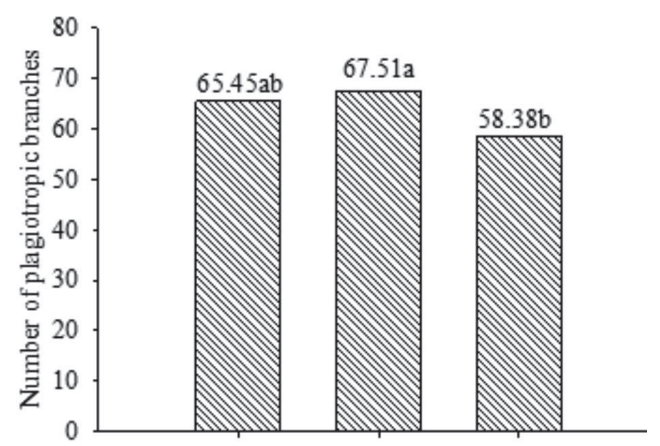

(D)

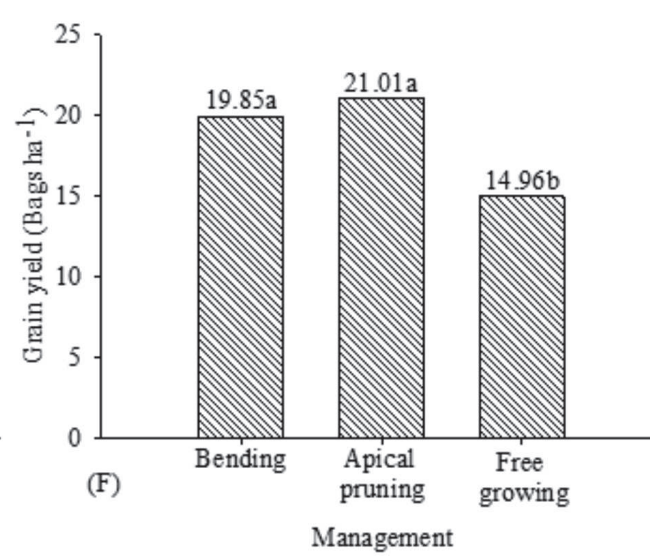

Figure 3: Vegetative characteristics and bean production of Coffea canephora conducted under different managements. Length of orthotropic shoot (A); Diameter of orthotropic shoot (B); Diameter of crown (C); Number of plagiotropic branches (D); Length of plagiotropic branches (E); Bean production (F). 
2012 and 2013 (Figure 1C), with accumulated monthly rainfall below $100 \mathrm{~mm}$. The low rainfall may have influenced the vegetative growth of the plants and, consequently, the final yield.

Water stress causes drastic reduction in growth and cell expansion rates (Silva et al., 2010; Vieira et al., 2013) and results in lower vegetative growth (Schmidt et al., 2015; Dalcomo et al., 2017). Moreover, high temperatures during the dry season (Figure 1A), typical of regions of equatorial climate, may compromise the vegetative growth of plants (Dubberstein et al., 2017). Therefore, studies on different planting times considering the use of irrigation can lead to different responses, resulting in greater or less efficiency of plant management practices.

\section{CONCLUSION}

Under the study conditions in Amazon South Western, the techniques bending and apical pruning were efficient to induce early growth of orthotropic shoots in Coffea canephora plants, resulting in higher yield of the first commercial coffee bean production.

\section{ACKNOWLEDGEMENTS, FINANCIAL SUPPORT AND FULL DISCLOSURE}

The authors want to thank the Brazilian Consortium for Coffee Research and Development for the financial support to this research (Project Code: 02.13.02.046.00.04.00) and to Coordenação de Aperfeiçoamento de Pessoal de Nível Superior (CAPES) for the scholarships granted to the second and third author.

The authors inform that there is no conflict of interests in carrying out the research and publishing this manuscript.

\section{REFERENCES}

Araujo RF \& Siqueira DL (2008) Avaliação de métodos de forçamento de brotação de borbulhas em citros. Revista Ceres, 55:450-454.

Dalcomo JM, Vieira HD, Ferreira A, Lima WL, Ferrão RG, Fonseca AFA, Ferrão MAG \& Partelli FL (2015) Evaluation of genetic divergence among clones of conilon coffee after scheduled cycle pruning. Genetics and Molecular Research, 14:15417-15426.

Dalcomo JM, Vieira HD, Ferreira A \& Partelli FL (2017) Growth comparison of 22 genotypes of conilon coffee after regular pruning cycle. African Journal of Agricultural Research, 12:6370 .

Dubberstein D, Partelli FL, Dias JRM \& Espindula MC (2017) Influência da adubação no crescimento vegetativo de cafeeiros na Amazônia sul ocidental. Coffee Science, 12:197-206.

ElShowk S, Ruonala R \& Helariutta Y (2013) Crossing paths: Cytokinin signalling and crosstalk. Development, 140:13731383.

Espindula MC, Partelli FL, Dias JRM, Marcolan AL, Teixeira AL \& Fernandes SR (2015) Condução de cafeeiros Coffea Canephora. In: Marcolan AL \& Espindula MC (Eds.) Café na Amazônia. Brasília, Embrapa. p.217-236.
Espindula MC, Schmidt R, Verdin Filho A, Fonseca AFA \& Dias JRM (2016) Poda de formação em cafeeiros Coffea canéfora. Porto Velho, Embrapa Rondônia. 6p. (Comunicado Técnico, 405).

Ferrão FG, Cruz CD, Ferreira A, Cecon PR, Ferrão MAG, Fonseca AFA, Carneiro PCS \&ßý Silva MF (2008) Parâmetros genéticos em café conilon. Pesquisa Agropecuária Brasileira, 43:61-69.

Marcolan AL, Ramalho AR, Mendes AM, Teixeira CAD, Fernandes CF, Costa JNM, Vieira Junior JR, Magalhães SJO, Fernandes SR \& Veneziano W (2009) Cultivo dos Cafeeiros Conilon e Robusta para Rondônia. $3^{\mathrm{a}}$ ed. Porto Velho, Embrapa Rondônia. 61p.

Marques VB, Moreira RA, Ramos JD, Araújo NA \& Cruz MCM (2012) Depth of planting and apical dominance on cuttings of red pitaya. Semina Ciências Agrárias, 33:2091-2098.

Mason MG, Ross JJ, Babst BA, Wienclaw BN \& Beveridge CA (2014) Sugar demand, not auxin, is the initial regulator of apical dominance. Proceedings of the National Academy of Sciences, 111:6092-6097.

Montagnon C, Cubry P \& Leroy T (2012) Amélioration génétique du caféier Coffea canephora Pierre: connaissances acquises, stratégies et perspectives. Cahiers Agricultures, 21:143-153.

Morais LE, Cavatte PC, Medina EF \& Silva PE (2012) The effects of pruning at different times onthe growth, photosynthesis and yield of conilon coffee (Coffea canephora) clones withvarying patterns of fruit maturation in southeastern Brazil. Experimental Agriculture, 48:210-221.

Ono EO, Grana Junior JF \& Rodrigues JD (2004) Reguladores vegetais na quebra da dominância apical de mamoeiro (Carica papaya L.). Revista Brasileira de Fruticultura, 26:348-350.

Partelli FL, Marré WB, Falqueto AR, Vieira HD \& Cavatti PC (2013) Seasonal vegetative growth in genotypes of Coffea canephora, as related to climatic factors. Journal of Agricultural Science, 5:108-116.

Rezende TT, Carvalho SP, Bueno Filho JSS, Honda Filho CP, Simões LC, Paulino RNL, Oliveira LL \& Nascimento TLC (2017) Propagação vegetativa do cafeeiro (Coffea arabica L.) por miniestacas. Coffee Science, 12:91-99.

Rocha RB, Vieria DS, Ramalho AR \& Teixeira AL (2013) Caracterização e uso da variabilidade genética de banco ativo de germoplasma de Coffea canephora Pierre ex Froehner. Coffee Science, 8:478-485.

Rodrigues WN, Colodetti TV, Brinate SVB, Martins LD \& Tomaz MA (2017) Genetic variability for sprout growth among genotypes of Coffea canephora led by bending of orthotropic stems. Genetics and Molecular Research,16:gmr16039813.

Schmidt R, Dias JRM, Espindula MC, Partelli FL \& Alves ER (2015) Poda apical e vergamento da haste principal na formação de cafeeiros clonais. Coffee Science, 10:266-270.

Silva VA, Antunes WC, Guimarães BLS, Paiva RMC, Silva VF, Ferrão MAG, Damatta FM \& Loureiro ME (2010) Resposta fisiológica de clone de café Conilon sensível à deficiência hídrica enxertado em porta-enxerto tolerante. Pesquisa Agropecuária Brasileira, 45:457-464.

Silva VA, Morais DLB, Kakida J, Ferreira EA \& Silva VF (2012) Concentração do ciclo de produção de pinhão-manso por meio de podas de formação ou de produção. Pesquisa Agropecuária Brasileira, 47:134-137.

Souza FF, Caixeta ET, Ferrão LFV, Pena GF, Sakiyama NS, Zambolim EM, Zambolim L \& Cruz CD (2013) Molecular diversity in Coffea canephora germplasm conserved and cultivated in Brazil. Crop Breeding and Applied Biotechnololy, 13:221-227. Bý 
Taiz L, Zeiger E, Moller IM \& Murphy A (2017) Fisiologia e Desenvolvimento Vegetal. $6^{\mathrm{a}}$ ed. Porto Alegre, Artmed. 808p.

Verdin Filho AC, Tomaz MA, Ferrão RG, Ferrão MA, Fonseca AFA \& Rodrigues WN (2014) Conilon coffee yield using the programmed pruning cycle and Different cultivation densities. Coffee Science, 9:489-494.
Vieira NG, Carneiro FA, Sujii PS, Alekcevetch JC, Freire LP, Vinecky F, Elbelt S, Silva VA, Damatta FM, Ferrão MAG, Marraccini P \& Andrade AC (2013) Different molecular mechanisms account for drought tolerance in Coffea canephora var. Conilon. Tropical Plant Biology, 6:181-190. 